\title{
Natural Theology and its Relevance to Religious Pluralism in Indonesia
}

\author{
David Kristanto, ${ }^{1 *}$ Daniel Runtuwene, ${ }^{2}$ Mozes Lawalata, ${ }^{3}$ Herman Poroe ${ }^{4}$ \\ ${ }^{1}$ Vrije Universiteit Amsterdam, Netherlands \\ ${ }^{2,4}$ Sekolah Tinggi Teologi Internasional Harvest, Tangerang, Indonesia \\ ${ }^{3}$ Sekolah Tinggi Teologi Injili Arastamar (SETIA) Jakarta, Tangerang, Indonesia \\ *Email: davidkristanto.id@gmail.com
}

\begin{abstract}
Natural theology is an underdeveloped theological theme in the recent Indonesian theological scholarship. That fact is unfortunate considering the significance of the topic to the context of religious pluralism in Indonesia. Natural theology is interdisciplinary and interreligious in nature; thus, it might open scholarly discussion for scholars from many disciplines with diverse religious backgrounds. Using a systematic theology approach, this article argues that developing natural theology could keep balance for Christian emphasis on general and special revelation that might lead toward the enrichment of the Christian faith.
\end{abstract}

Key Words: theology, natural theology, religious studies, religious pluralism, interreligious dialogue

Article History:

Submitted: May 06, 2021

Revised: July 23, 2021

(c) (i) (2)
Published: Jan. 27, 2022

This is an open access article under the CC BY-SA license

\section{INTRODUCTION}

Within the last five years, few journal articles on or related to natural theology have been produced in Indonesia. Hermawan's article is a response to process theology (a branch of natural theology), which is accompanied by sincere appreciations, yet ends with a conclusion that there should be a clear division between natural theology and biblical Christian theology (Hermawan, 2019, p. 57). Two other articles on natural theology sound more appreciative complemented with attempts to present the potential contribution of natural theology to the context of Indonesia. Wijoyo argues that Alister McGrath's natural theology could offer a moral contribution to Indonesian society, while Nassa, who is also working on McGrath's natural theology attempts to present a systematic introduction and seeks to show the potential contribution that McGrath's natural theology might offer compared to other natural theologies (Nassa, 2020; Wijoyo, 2017).
Where a discussion of natural theology could help the Indonesian context is in relation to pluralism. Peter Berger defines pluralism as, "a social situation in which people with different ethnicities, worldviews, and moralities live together peacefully and interact with each other amicably" (Berger, 2014, p. 1). Religion is included within the context of this plurality, and since religion generally determines people's worldviews, religious pluralism is of vital importance to society.

Plurality of worldviews is never without problems. In Indonesia, clashes of worldviews are often inevitable (Salurante, 2021, p. 17). Berger points out the political problem of such pluralism. While fundamentalism balkanizes people, relativism undermines the society's moral consensus which is an indispensable aspect for the society to survive. Thus, the society should maintain the middle ground between the two extremes to overcome the problem (Berger, 2014, p. 15). 
The primary argument of this paper is that natural theology has strong relevance to the Indonesian context, especially to the context of religious pluralism in Indonesia. The interdisciplinary and interreligious nature of natural theology could open huge opportunities for dialogues and interactions among religious communities, so it might guard against the balkanization of the religious groups from each other. And even though this article will focus more on developing a Christian natural theology, it also argues that there are possibilities of developing a natural theology from the viewpoint of other religious traditions, such as Islamic natural theology, Hindu natural theology, and so on. By doing so, the religious communities might glean a deeper understanding of their faith so they could guard against relativism. Natural theology might also be helpful for initiating interreligious dialogues in the context of Indonesia's pluralistic society.

\section{METHOD}

This research is a systematic theology study on the topic of natural theology and its possible relevance to religious pluralism in Indonesia. Systematic theology research is an attempt to study what the Bible teaches on particular topics (Smith, 2019 , p. 139). Works related to the topic are critically reviewed to gain a comprehensive and systematic theological understanding of the topic, so the relevance of the topic toward the context of religious pluralism in Indonesia could be drawn. This article will first deal with the definition and scope of natural theology; second, the emphasis of natural theology on the role of the nature or general revelation and the relevance of that particular emphasis to religious pluralism in Indonesia; third, the possibility of constructing a Christian natural theology and its relevance toward enrichment of the Christian faith; and fourth, this article will end with a conclusion.

\section{RESULTS AND DISCUSSION}

\section{Definition and Scope of Natural Theology}

De Cruz and Smedt define natural theology as a theological method that examines God's existence and attributes without reliance on special revelation (Cruz \& Smedt, 2015, p. 5). Natural theology places general revelation or nature as it is experienced in daily life as a starting point on doing theology. Due to that theological method, natural theology is often understood as philosophical theology.

However, it is important to note that there is no single ultimate definition of natural theology. According to McGrath, there are at least six views on natural theology. First, natural theology is understood as a branch of philosophy which explores the possibility of knowing God through reason alone, without the aid of revelation; second, natural theology as a demonstration or affirmation as the existence of God based on the order and complexity of the cosmos; third, natural theology as a result of an intellectual endeavor that springs from human natural desire to know God; fourth, natural theology as an explaining the coherence between human intellectual experience and the Gospel; fifth, natural theology as an effort to demonstrate how naturalistic approach and achievements of natural sciences are insufficient to provide a comprehensive explanation of the order of the cosmos without complemented by theological concepts; and sixth, natural theology as a theology of the nature, a Christian understanding of the nature based on Christian faith, an approach fully in contrast with the naturalist approach which seeks to set faith aside (McGrath, 2017, pp. 18-21). Due to the diversity of views on natural theology, McGrath argues that natural theology is best understood as a certain framework to understand the nature and God, rather than a specific theory about the world or God (McGrath, 2017, p. 24).

The approaches on developing natural theology are also varied. Cruz and Smedt argue that in general, there are at least three approaches of 
natural theology. The first approach, which is most popular and most developed, is providing arguments that defend or against God's existence such as the cosmological argument and the moral argument. The second approach has more emphasis on the nature and its relationship with the human desire and beliefs. This approach highlights how human mind has a natural inclination to be oriented toward God. The third approach does not attempt to prove the existence of God, it rather builds a theology about nature on the basis of the assumption of God's existence. This approach is an attempt to interpret nature theologically while assuming the existence of God (Cruz \& Smedt, 2015, p. 6).

Natural theology is not limited to a particular religious tradition. Even though many of its practitioners are adherents of monotheism, some polytheistic thinkers from India and ancient Greece have also developed natural theology significantly. Natural theology has also been developed by atheist and agnostic thinkers such as Hume and Voltaire, which can also be found in the recent works of Trakakis and Schellenberg, related to the problem of evil and the hiddenness of God (Cruz \& Smedt, 2015, p. 6).

The interdisciplinary and interreligious nature of natural theology is relevant to the context of religious pluralism in Indonesia. It is interdisciplinary since both theologians and philosophers engaging in the discussion. Multiple approaches have been employed by those thinkers opening even more opportunities for rich engagements with the topic in the future. Furthermore, its interreligious nature is very important to spark interest in initiating interreligious dialogues.

Louis Roy argues that the first among other principles to build a fruitful interreligious dialogue is to find a "mutual attunement" so the people who are engaging in the dialogue would discover that rather than differences, they have more things in common. A good starting point to initiate such a dialogue emerges when both dialogue participants feel that they both think, feel, and care about particular things (Roy, 2019, p. 182). Natural theology could be a common ground that builds that "mutual attunement" between people from different religious traditions. Through engaging with natural theology, people from different religions could sense that they actually have more things in common.

The fact that natural theology is also being developed by atheist and agnostic thinkers shows how developing natural theology might help the religious communities in Indonesia to engage with the issue of atheism and agnosticism. For a more specific Christian purpose, natural theology could be a tool for doing apologetics to the atheists and agnostics. In particular, the emphasis of natural theology on the nature or the cosmos could be a starting point on building an interreligious "mutual attunement."

\section{Nature and Natural Theology}

The history of natural theology in the West could be traced back to Ancient Greek philosophy. From the record of Xenophon (4 B.C.E), we might know that Socrates had argued about two possibilities of the origin of the living things (Cruz and Smedt 2015, p. 7; cf. Xenophon 1997, pp. 299309). The first was through design, and the second was through chance. If life seemed to have a purpose, then, there should be a design behind it. This life could not have a purpose if it came out through mere chance. There was also a Stoic philosopher, Cicero, argued that the order of the cosmos gave strong proof of the existence of the gods. Natural theology has also been developed by the Hindu theologians. They developed arguments from design and also cosmological arguments as reactions against materialism, atomism, and other variants of Buddhism and Samkhya (Cruz \& Smedt, 2015, pp. 7-8).

Given those examples, it is clear how natural theology puts a strong emphasis on nature or the cosmos. Such an emphasis would also be relevant to the context of religious pluralism. Natural theology provides some important starting points for interreligious dialogues. Most religions 
have their own scriptures and their own "book of nature." This provides an important opportunity to reflect on how different religious traditions interpret nature, opening up a new perspective for comparative theology and interreligious dialogues. There is potential to reflect and discuss upon how different religious communities understand nature theologically (McGrath, 2017, 155).

Even though it is important to appreciate natural theology's noble emphasis on nature, it is also crucial to note that Christian thinkers see nature as general revelation. Biblical text such as Psalm 19 proclaims that nature is revealing the glory of God. As Jesus himself is part of the world of nature N. T. Wright argues that we should include him when discussing about the nature and the development of natural theology (Wright, 2019, p. 2).

Emil Brunner argues on the ground of 1 Corinthians that human beings, regardless of being Christian or not, are the image of God. His understanding of imago Dei leads him to an agreement with the historic scholasticism that rational natural theology is possible (Brunner 1939, pp. 499-501; cf. Wall 2018, pp. 35-36). Brunner is apt on linking the status of humanity as imago Dei and human natural capacity to know God. Despite their strong opposition toward a natural theology that is free from revelation, Junius and Van Til affirm that, even after the fall, the doctrine of the image of God still refers to both theological and God-relational nature of human beings (Shannon, 2020, p. 300). The cosmos and humanity are indeed the legitimate common ground to build a natural theology, and thus could provide a starting point conversing with people from other religious traditions. However, from a Christian viewpoint, it is important to note the organic unity between nature as God's general revelation and Scripture as God's special revelation.

Herman Bavinck strongly disagrees with any theological method that severs the connection between general and special revelation, between nature and grace. Revelation is seen as identical with all of God's work in nature. Special revelation is seen as based on God's general revelation. However, Bavinck argues that neither nature nor history could reveal us the "unalterable will of God" to save sinners. While in creation God manifests his mind, in the special revelation, he discloses the greatness of his heart. Redemption is the center of the special revelation that distinguishes special revelation from the general revelation (Bavinck 2018, p. 23). Abraham Kuyper is in tune with Bavinck when he argues that even though there is only one knowledge of God, but there are "two sources of the knowledge of God," which are nature and scripture (Kuyper 1980, p. 377; Muller 2019, p. 17). Natural theology should indeed put a special emphasis on nature. However, it is untenable to separate nature from scripture or the general revelation from special revelation. The role of the special revelation should not be seen as diminishing the value of nature in doing theology, but it should be seen as a lens or a theological framework for us to see nature in a better way.

On the relevance of natural theology to religious pluralism in Indonesia, three examples will be provided below. The first example is an interreligious dialogue about the relationship between human and other things in nature. Samsul Maarif identifies the uniqueness of the indigenous paradigm from Ammatoa Kajang religious community in South Sulawesi that comprehends the relationship between humankind and nature as inseparable. Humankind is not seen as hierarchically higher than nature as it is in the understanding of subject-object relationship; instead, humankind and nature are seen in a subject-subject relationship as coined by Maarif as "intersubjective relations." They understand the mountain as a subject which has shown its commitment to share with the other creatures in the environment which include humankind. Therefore, when they come up to the mountain to present offerings (Bahasa Indonesia: "sesajen"), they are not worshipping the mountain but showing their commitment to share with the mountain in an intersubjective relationship (Maarif 2015, pp. 33-4). 
The Dutch Statesman-Theologian, Abraham Kuyper, called upon his followers to live up the principle of "palingenesis" to overcome the rise of pantheism in the nineteenth century Europe. He drew that term from the Greek word palingenesia, found in Titus 3:5 as referring to personal rebirth or regeneration and in Matthew 19:28 as referring to the rebirth of all creations into the new heaven and new earth (Bartholomew 2017, pp. 316-7; Kuyper 1998, p. 398).

This principle of palingenesis could be a starting point to converse with the "intersubjective relations" explained above by Maarif. The difference between the two is that instead of describing the relationship between human-kind and other creations as subject-subject relationship, palingenesis shows us a picture of object-object relationship. For the message of salvation is not understood as limited only to human souls but also to the restoration of nature or the whole cosmos, humankind and other creations are both seen as the objects of God's love. Despite the difference, conversation between them could lead toward mutual agreement that humankind and nature are in a non-hierarchical relationship.

The second example is an interreligious dialogue about natural disaster. Because of living in the ring of fire, the people in West Bandung area develop their own theology of disaster when responding to the potency of earthquake in their area. The people there could be generally classified as belong to the Asy'ariyah school of Islam. Through their religious perspective, the earthquake is seen as God's decree or will, or God's activity of testing his people so they could be more patient, or it could also be a call to repent (Kosasih et al. 2021, p. 1).

An Old Testament theologian, John Walton, categorizes the creation process as "order," "nonorder," and "disorder." The first refers to what God calls as "good" in his creation, the second refers to what has not yet been completely resolved into a "fully ordered world." And the third category, "disorder," refers to the fall of humanity into sin. While the situation before the fall was the world progressing toward completeness of what is good or ordered, sin is seen as a disturbance to that ordering process, or to put it in Walton's category, bringing "disorder" into the world. Natural disaster belongs to the "nonorder" category that exists due to the unfinished creation process, yet not to the "disorder" category. From this perspective, the relationship between sin and natural disaster is an indirect one. Natural disaster is due to the unfinished creation work of ordering (the "nonorder" category), while committing sin (the "disorder" category) is a disturbance to that creation work of ordering that might pushes away the "nonorder" from the world (Walton 2017, p. 185).

The dialogue between Walton's theology and the theology of disaster of the West Bandung people could be about the relationship between sin and disaster. While Walton would say that the relationship is indirect, the West Bandung people are open to the possibility of direct relationship between their sins and the natural disaster that occurs in their area. How does the different perspective between the two affect the religious praxis of the people? That might be an interesting topic for them to discuss.

The third example is a dialogue about humanity. Since human beings are considered as part of nature, natural theology could also be developed upon the basis of theology of humanity, as it is done by the Sufism community in Pekalongan. Maulana calls their theology as a "theology of humanity" because it does not emphasize the transcendent elements of theology but the social activities such as helping others. Their theology of humanity encourages them to give medical and economic assistance to the others within their community (Maulana 2019, p. 25).

In Christian tradition, C. S. Lewis is one among others who proposed a natural theology based on humanity. He advances his argument from morality. Lewis says that if we compare the moral teaching of "the ancient Egyptians, Babylonians, Hindus, Chinese, Greeks and Romans," we will find striking similarities among them. Running from battle has never been praised, as it is perceived as 
selfish. Even though men would differ on whether one should marry one or four wives, they would all agree that there are certain marriage rules to hold (Lewis 2016, p. 6). The fact that there is a kind of universal moral law points to the existence of a Power, a Director, or a Guide. Lewis agrees that this point cannot be taken as a direct reference to the Christian God, however, this is a step further toward acknowledging God's existence (Lewis 2016, p. 25).

The dialogue between the two could be about variety of topics. It might proceed to talk about the moral attributes of God, the right morality, nature of sin or wrongdoings, or about whether God's transcendent existence could be inferred from things that are immanent, such as our morality or our daily human activities.

\section{Christian Natural Theology}

Alister McGrath argues that even though natural theology is not limited to Christianity, it is possible to construct a Christian natural theology. $\mathrm{He}$ starts by arguing that if we limit the understanding of natural theology as, "the branch of philosophy which investigates what human reason unaided by revelation can tell us concerning God," the concept of a "Christian natural theology" would be to some extent problematic (McGrath, 2017, p. 26). Though it is still possible to speak about how natural theology might lead someone to Christianity, constructing a Christian natural theology is much more than having that kind of neutral ground to lead someone to Christianity. What is suggested by McGrath is to construct a natural theology from a distinctly Christian perspective, and to do so, one should challenge the notion that natural theology should be "unaided" by any kind of revelation. For McGrath, we should have four "serious concerns" to that notion.

The first concern is about how the notion that natural theology should be totally free from the aid of revelation assumes that there is one universal way of human reasoning. This assumption is the very project of the Enlightenment, emphasizing the universality of reason that is, "independent of the historical and cultural location of the thinker." McGrath argues that this assumption is untenable except in specific areas of mathematics and logics. He agrees with Thomas Nagel that, "every viewpoint is actually a view from somewhere" (McGrath, 2017, pp. 27). The emergence of forms of natural theology that sought to demonstrate God's existence by reason alone dates from the seventeenth and eighteenth centuries, those centuries were when rationalism was at the height of its influence. Earlier thinkers such as Anselm of Canterbury and Thomas Aquinas were concerned with a more balanced emphasis on reason and faith on demonstrating the existence of God (McGrath, 2017, pp. 27-8).

The second concern to the notion that natural theology should be free from revelation is that it fails to recognize how the human mind is doing a constructive activity while observing. Any observations done by human minds are not a "passive reception of impressions from the external world." The human process of perception always involves interpretation. Observation is never neutral, instead, it is a "theory-laden" process that involves "implicit conceptual schemas," that are open to be challenged (McGrath, 2017, p. 30).

The third concern to the notion that natural theology should be without the aid of revelation is that it fails to appreciate "tradition-mediated rationalities." The project of the Age of Reason seeks to confront the world through empirical means and without any presuppositions but only with "objectified standards of rational justification" that are independent from all "social and cultural particularities." McGrath cited Alasdair MacIntyre to point out how that project has failed and suggested following MacIntryre on acknowledging the role of tradition and communities in every rational discourses. There is no such a thing as a "neutral" or "universal" viewpoint which a "tradition-independent" natural theology could be done. Natural theology is unlike mathematics, for it always arises from within and informed by a certain intellectual tradition (McGrath, 2017, pp. 31-2). 
The fourth concern points out how the notion that natural theology should be free from the aid of revelation is the inattentiveness of nature to the moral, intellectual, and aesthetic values. One example is how the idea that natural landscapes are beautiful in themselves is quite recent. People from earlier centuries tended to modify the natural landscapes into constructed gardens, making them more beautiful as they perceived at times. Few people regarded nature as possessing aesthetic merit without being modified by humans. That shows how nature is, "intellectually, morally, and aesthetically ambiguous." McGrath suggests that the meaning of nature should be "unlocked" with a key that could not be find in nature itself (McGrath, 2017, p. 33).

A Christian natural theology deals with imagining nature from a Christian perspective. The Enlightenment was uneasy toward taking imagination seriously for it might lead to retreating into an imaginary world. To refute that uncritical accusation, McGrath cites Iris Murdoch, that there is a distinction between an untruthful "egoistic fantasy," and the "liberated truth-seeking creative imagination," that freely explores the world in a creative way, seeking to discern what is deep and true (McGrath, 2017, p. 49). This concept of Christian imaginarium is highlighted by McGrath to show the limit of sensorium, the human sense that is always determined by cultural, biological, and social influence. How we feel, understand, and interpret the world are not neutral; thus we have to be transformed through metanoia in order to enable us to develop a Christian imaginarium that makes it possible to see the beauty of nature as it is (Nassa, 2020, 23). McGrath argues that the Christian imaginarium is not a call toward retreating to the imaginary world, but it refers to the divine "transformed capacity" of understanding and seeing things in reality that is resulted from metanoia; enabling us to grasp reality more deeply, using both imagination and reason, giving us "new competencies" and "new functions", while opening us to the "new possibilities" (McGrath, 2017, p. 43).
McGrath provides an example of how human nature is always prone to the inability to see "things as they really are" through the example of a stone from the Canford School in Dorset in southern England. The school was established in 1923 when an old country manor was purchased and renovated for educational purposes. This house was previously owned by Sir Henry Layard (1818-94), a wellknown Victorian archaeologist who spent most of his time digging archaeological sites in Mesopotamia known for the discovery of Nineveh, the "lost" city, in 1845. In one of the rooms of that school, there is a stone slab which is believed to be a replica of an ancient Assyrian carving. In 1994, Columbia University art history, professor John M. Russel visited that school to study Layard's life. While exploring the school, the professor found that the stone slab was a real 3,000 year-old carving board that was taken from the room of Assyrian King Yasul Nasirpa II (883-859 BC). The stone was sold at auction for 11,8 million USD. That new information allowed people to see the true face of this stone. The stone itself has not changed, but the perspective of that stone has changed (McGrath, 2017, pp. 50-1).

A Christian natural theology enables us to see the natural world in the right way. The inability of our eyes to see properly is healed and the veil has been removed from our eyes. McGrath argues that the Greek term metanoia which has been inadequately translated as "repentance" is not primarily referring to "a sense of regret," but a renunciation of views that are narrow and sectarian that are not sufficient to appreciate God's mystery. It is a "transformed metaphysical vision" to perceive the reality (McGrath, 2017, p. 51). It shall be argued further that with knowledge from Scripture, we would understand nature better. One example is from the book of Genesis. Genesis opens with the portrait of how heaven and earth were created as a construction of a temple. It was built in seven stages, like the construction of a temple, and the final element is the image, which reflects the divine presence in the world that might channel back 
worship from the creation back to the Creator (Wright, 2019, p. 5). Without the information we gain from Scripture, it is not possible to see the world as a temple created to be filled by the glory of God. We might conclude that there must be a Creator who creates this world, but the relationship between the Creator and the world he created would be unclear.

Reflecting upon the theme of natural theology would bear fruitful theological reflection that enriches the Christian faith, especially in the Indonesian context. Nature (general revelation) and scripture (special revelation) are not to be separated but taken together for they both reveal one knowledge of God. Instead of overemphasizing the role of the scripture as special revelation at the cost of sacrificing the role of nature as general revelation; Christians are called to develop a Christian imaginarium that leads toward a deeper understanding of nature as God's creation to enrich our Christian faith. Taking the whole revelation of God, a Christian imaginarium would lead Christians to see nature as the place where God's glory is revealed, where the people should worship and glorify God.

\section{CONCLUSION}

Natural theology is a highly relevant topic for the context of religious pluralism in Indonesia. The interdisciplinary and interreligious nature of natural theology might open more discussions for

\section{REFERENCES}

Bartholomew, C. G. (2017). Contours of the Kuyperian Tradition. IVP Academic.

Bavinck, H. (2018). Philosophy of Revelation: A New Annotated Edition (Cory Brock and Nathaniel Gray Sutanto (ed.)). Hendrickson.

Berger, P. L. (2014). The Many Altars of Modernity. De Gruyter.

Brunner, E. (1939). Man in Revolt: A Christian Anthropology (O. Wyon (trans.)). Lutterworth.

Cruz, H. De, \& Smedt, J. de. (2015). A Natural scholars from multiple disciplines with diverse religious backgrounds. For theological scholarships in Indonesia, this theological topic might open discussions and joint research for scholars from many religious educational institutes. This topic could be developed creatively without any inherent and definitive boundaries.

Natural theology could provide a common ground that is needed to foster interreligious dialogues in Indonesia. The theme has been developed for ages and loaded with so many quality resources from many disciplines and religious backgrounds. To develop this theme, Indonesian scholars do not need to start from nothing, but they could start by re-reading and re-interpreting the available resources on the topic, then develop unique Indonesian approaches on the theme.

Christians should not be afraid of developing natural theology. The role of Scripture as God's special revelation would not be diminished, since it is completely possible to develop a distinct Christian natural theology. It is possible to re-interpret nature through the lens of Scripture, so the beauty that is instilled by God in nature could be seen as it is. Another important point is that natural theology could emphasize the importance of keeping together general revelation and special revelation in every theological enterprise. The two should always be taken together for they are inseparable; and even though there are two ways to know God, there is only one true knowledge of God.

\section{History of Natural Theology: The Cognitive Science of Theology and Philosophy of Religion. MIT Press.}

Hermawan. (2019). Respons terhadap Konsepsi Allah dalam Teologi Proses. Pengarah: Jurnal Teologi Kristen, 1(1), 50-58.

Kosasih, A., Surahman, C., Yuniartin, T., \& Firmansyah, M. I. (2021). Theology of disaster: A study on west bandung people's responses to the potency of earthquake. IOP Conference Series: Earth and Environmental 
Science, 683. https://doi.org/10.1088/17551315/683/1/012076

Kuyper, A. (1980). Principles of Sacred Theology (J. H. De Vries (trans.)). Baker.

Kuyper, A. (1998). The Blurring of the Boundaries (1892). In J. D. Bratt (Ed.), Abraham Kuyper: A Centennial Reader (pp. 363-402). Wm. B. Eerdmans.

Lewis, C. S. (2016). Mere Christianity. William Collins.

Maarif, S. (2015). Kajian Kritis Agama Lokal. In S. Maarif (Ed.), Studi Agama di Indonesia: Refleksi Pengalaman (pp. 21-40). Center for Religious \& Cross-cultural Studies.

Maulana, L. (2019). Theology of Humanity in the Sufism Community of the Sabbaqal Mufarridiyah Group in Pekalongan Indonesia. JURNAL PENELITIAN, 16(1), 25-36. https://doi.org/10.28918/jupe.v16i1.1832

McGrath, A. E. (2017). Re-Imagining Nature: The Promise of A Christian Natural Theology. Wiley-Blackwell.

Muller, R. A. (2019). Kuyper and Bavinck on Natural Theology. Bavinck Review, 10, 5-35.

Nassa, G. S. (2020). Pengantar kedalam Teologi Natural Alister E. McGrath. Pengarah: Jurnal Teologi Kristen, 2(1), 15-32.

Roy, L. (2019). Principles of Fruitful Interreligious Dialogue. Studies in Interreligious Dialogue, 29 ,

159-183.
https://doi.org/10.2143/SID.29.2.3287305

Salurante, T. (2021). Wawasan Dunia Kristen Dan Panggilan Gereja: Arah Gereja Modern Bermisi. Evangelikal: Jurnal Teologi Injili Dan Pembinaan Warga Jemaat, 5(1), 16. https://doi.org/10.46445/ejti.v5i1.328

Shannon, N. D. (2020). Junius and Van Til on Natural Knowledge of God. Westminster Theological Journal, 82, 279-300.

Smith, K. G. (2019). Writing \& Research: A Guide for Theological Students. Langham Global Library.

Wall, M. (2018). The Legacy of Emil Brunner's Approach to Natural Theology. Didaskalia, 28, 30-48.

Walton, J. H. (2017). Old Testament Theology for Christians. In The Christian Librarian (Issue 1). IVP Academic.

Wijoyo, H. (2017). Persahabatan: Sumbangsih Moralitas Tradisi Kristen bagi Moralitas Bangsa Indonesia. Veritas: Jurnal Teologi Dan Pelayanan, 16(2), 169-182. https://doi.org/10.36421/veritas.v16i2.17

Wright, N. T. (2019). Jesus in Space, Time, and History: Natural Theology and the Challenge of Talking about God. CRUX, 55(4), 2-11.

Xenophon. (1997). Memorabilia. In E. C. Marchant \& O. J. Todd (Trans.), Memorabilia, Oeconomicus, Symposium, Apology (pp. 1359). Harvard University Press. 